\title{
International Regulations and Guidelines on Transboundary Salmon Stocks: Case Study of the Tana River
}

\author{
Irene Vanja Dahl \\ UiT The Arctic University of Norway
}

\begin{abstract}
The year 2019 was "the international year of the salmon" (IYS). The overarching aim was "to inform and stimulate outreach and research that aspires to establish the conditions necessary to ensure the resilience of salmon and people throughout the Northern Hemisphere;" further, to bring people together, share and develop knowledge, raise awareness and take action. This article is intended as a contribution to this goal. The article discusses how international law: the Law of the Sea Convention, the Convention on Biological Diversity and the Convention for the Conservation of Salmon in the North Atlantic Ocean relate to conservation and management of wild salmon. The article has a special focus on bilateral cooperation on salmon stocks in boundary/ transboundary rivers, and using as a case study the Tana river in Norway and Finland.
\end{abstract}

Keywords: anadromous stocks, Atlantic salmon, Law of the Sea Convention, North Atlantic Salmon Conservation Organization, bilateral cooperation, border river, Tana River, ILO-convention 169, indigenous people

Responsible Editor: Øyvind Ravna, Faculty of Law, UiT The Arctic University of Norway

Received: June 2020; Accepted: October 2020; Published: December 2020

\section{Introduction}

The year 2019 was "the international year of the salmon" (IYS), initiated by the North Atlantic Salmon Conservation Organization (NASCO) and the North Pacific Anadromous Fish Commission (NPAFC). According to the home page of

\footnotetext{
^Correspondence to: Irene Vanja Dahl, email: irene.dahl@uit.no

(C) 2020 Irene Vanja Dahl. This is an Open Access article distributed under the terms of the Creative Commons AttributionNonCommercial 4.0 International License (https://creativecommons.org/licenses/by-nc/4.0/), allowing third parties to share their work (copy, distribute, transmit) and to adapt it, under the condition that the authors are given credit, that the work is not used for commercial purposes, and that in the event of reuse or distribution, the terms of this license are made clear.

Citation: Irene Vanja Dahl. "International Regulations and Guidelines on Transboundary Salmon Stocks: Case Study of the Tana River" Arctic Review on Law and Politics,Vol. 11, 2020, pp. 157-188. http://dx.doi.org/10.23865/arctic.v11.2432
} 


\section{Irene Vanja Dahl}

IYS, the overarching aim was "to inform and stimulate outreach and research that aspires to establish the conditions necessary to ensure the resilience of salmon and people throughout the Northern Hemisphere;" further, to bring people together, share and develop knowledge, raise awareness and take action. ${ }^{1}$ This article is intended as a contribution to this goal from an international law perspective, drawing on the example of bilateral cooperation on the Tana River in northern Norway and Finland.

Since the 1970s there has been a marked reduction in the abundance of salmon, prior to reductions in other fisheries. ${ }^{2}$ Atlantic salmon stocks in Norway are half what they were in the 1980s. ${ }^{3}$ However, in northern Norway, stocks have been quite stable for the past 30 years, with one significant exception: the Tana River, which has experienced a major decline in the past $10-15$ years. ${ }^{4}$ In 2020 , the Norwegian scientific advisory board for salmon management characterized the status of several salmon stocks in the Tana Watercourse as "very poor."

The Tana River serves as a border between Norway and Finland; it is part of the Tana Watercourse and is one of the largest salmon rivers in Europe.

The Tana Watercourse is located mainly in the Norwegian municipalities of Tana, Karasjok, and Kautokeino and in the Finnish municipality of Utsjoki, and is home to some 30 genetically distinct stocks of salmon. ${ }^{6}$

The principal river of this watercourse is the Tana River. It is $211 \mathrm{~km}$ long, and most of it serves as boundary line between Norway and Finland. ${ }^{7}$ Total annual Norwegian and Finnish catches vary from 50 to 250 tons (15 000-60 000 salmon units), ${ }^{8}$ decreasing in recent years: the average annual catch for 1972-2007 was 126 tons, whereas the average for 2007-2017 was 93 tons. $^{9}$

According to the salmon registry of the Norwegian Environment Directorate, the status of Tana River salmon is "very bad" as to spawning stock and harvesting potential, but "very good/good" as to genetic integrity. ${ }^{10}$ Of the 18 impact factors identified, foreign fish species are regarded as having moderate impact, whereas overexploitation is seen as great. ${ }^{11}$

The Norwegian Ministry of Foreign Affairs has also indicated that several salmon stocks in the Tana Watercourse are exposed to significant overexploitation, although impacted to a much lower degree by other kinds of human activity than fishing. ${ }^{12}$ In 2017, the Ministry concluded that salmon fishing would have to be reduced in order to rebuild the endangered stocks. ${ }^{13}$

In addition to the Tana River, the region of Troms and Finnmark hosts the transboundary salmon rivers Neidenelva (Norway/Finland) and Jakobselva (Norway/Russia). Multi-nation management regimes may represent risks to salmon stocks, especially if shifting domestic regimes are involved. The analysis of international regulations and guidelines in this article also has some application to these rivers, but the focus here is on the Tana River, for which there exists an updated bilateral agreement applying to the Tana Watercourse (hereafter: the Tana Agreement). ${ }^{14}$ 


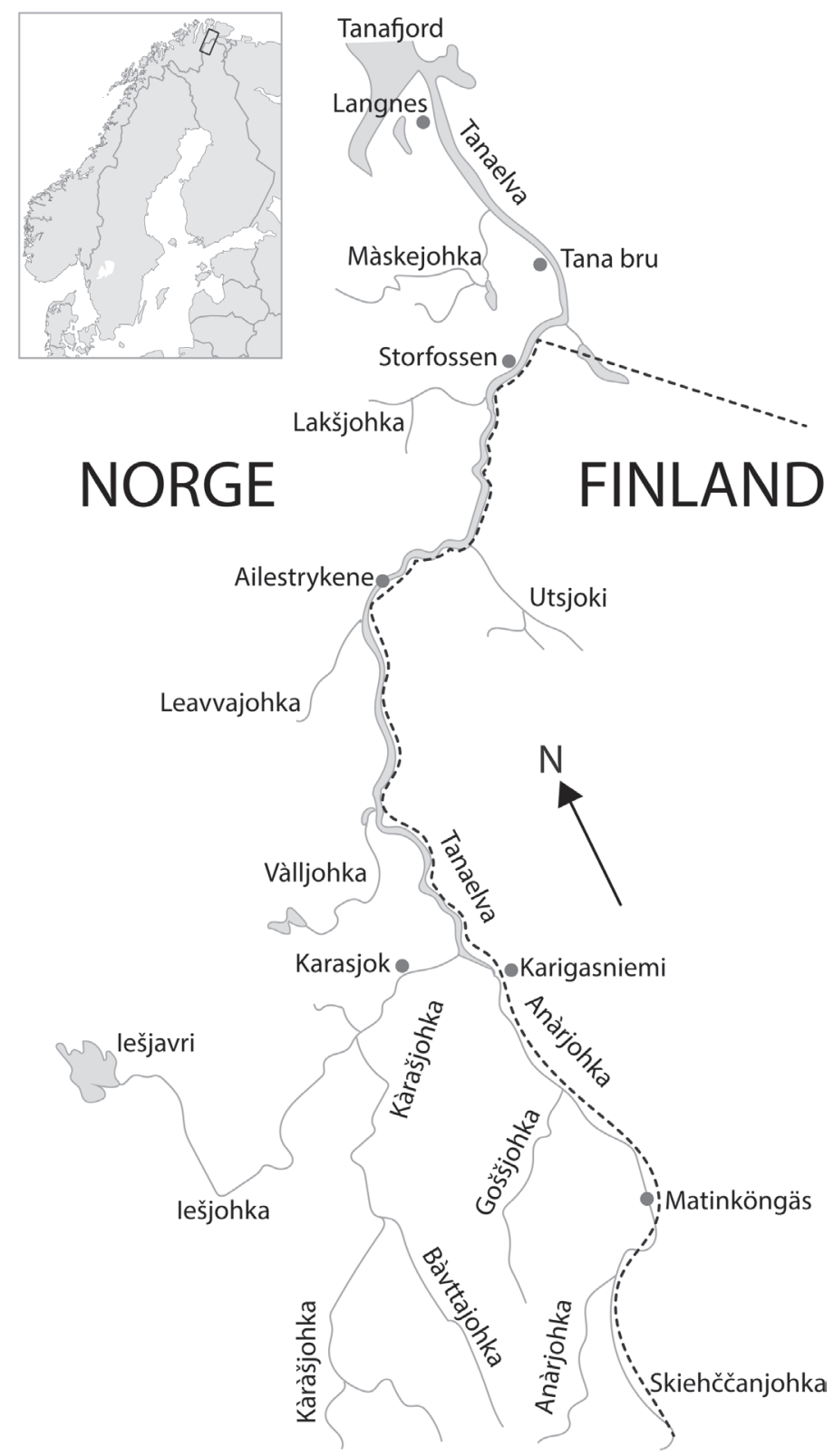

The Tana River serves as a border between Norway and Finland. It is part of the Tana Watercourse and is one of the largest salmon rivers in Europe. Map: Bjørn Hatteng, UiT The Arctic University of Norway, with permission from the copyright holder, Tanavassdragets fiskeforvaltning.

As pointed out, the sustainability aspect is significant regarding the salmon in the Tana River. However, the indigenous peoples aspect also applies to the salmon management of the Tana River (in Sami: Deatnu), as the river is subject to traditional Sami salmon fishing. The article will focus on these two aspects, both of which are 


\section{Irene Vanja Dahl}

covered by various international legal instruments. The main research question to be discussed, is whether the Tana Agreement is concluded and implemented in accordance with the larger frameworks of international law, aiming on the one hand to secure sustainable use and conservation of the salmon, and on the other hand to secure the indigenous rights and interests of the Sami people.

\section{Relevant international law}

\subsection{The United Nations Convention on the Law of the Sea (LOSC)}

In this section, I will discuss the relevance of the most basic treaties when it comes to the two significant aspects of salmon management in the Tana River: conservation of salmon through bilateral cooperation and protection of Sami interests.

As for all questions related to management of marine resources, the legal basis for discussions is the United Nations Convention on the Law of the Sea (LOSC). ${ }^{15}$ In Article 66, the LOSC deals with anadromous stocks. The Article recognizes that the state of origin has primary interest in, and responsibility for, such stocks. Although the LOSC does not define "state of origin," a logical definition is "the state in whose rivers these stocks spawn." 16

As the salmon stocks spawn on both sides of the river, both Norway and Finland should be regarded as "state of origin." Hence, both Norway and Finland should be assigned "the primary interest in and responsibility for such stocks," as per LOSC Article 66(1). Further, the state of origin is obliged to ensure the conservation of these stocks (LOSC Art. 66(2), through "the establishment of appropriate regulatory measures for fishing in all waters landward of the outer limits of its exclusive economic zone [...]." This duty obviously applies to the exclusive economic zone (EEZ) and the territorial sea of the coastal states.

The question is whether the obligation to establish conservation measures also applies to (trans)boundary rivers, as the wording "waters" does not cover rivers.

In order not to undermine measures applicable to the EEZ and the territorial sea, this duty should apply to rivers as well. The question arises whether such an obligation derives from international customary law. In other words, whether Article 66(2) of LOSC has become customary international law, and thus establishes a corresponding conservation obligation regarding (trans)boundary rivers. Roach has collected opinions from international courts and tribunals, governments and scholars, who have identified various provisions of LOSC that they claim to be customary international law, and thus binding on all states. ${ }^{17}$ The only opinion on Article 66 that Roach has found, is that "The United States has expressed the view that Article 66(3)(a) on fishing for salmon on the high seas reflects customary international law." It follows from this provision, that if fisheries for anadromous stocks in the EEZ and territorial sea results in economic dislocation for a state other than the state of origin, fishing on the high seas may take place under stipulated conditions. There is a long 'way' from the high seas to a river, and the view of the United States can hardly serve as a basis 
for any regulation obligation regarding rivers. The drafters of Article 66 probably did not envisage a shared river situation. In addition, the strict concept of territorial sovereignty as reflected in Article 2 of LOSC, supports this opinion. An international law obligation on states regarding the regulation of salmon in rivers, as a matter subject to territorial sovereignty, must have a more solid and thorough legal foundation than an expansive interpretation of one state's opinion on a quite specific LOSC Article on fisheries for anadromous stocks on the high seas as being international customary law.

However, as we will see in the discussion below, such a legal foundation exists, at least to a certain degree.

\subsection{The Convention on Biological Diversity (CBD)}

The Convention on Biological Diversity may serve as a legal foundation for an obligation to conserve salmon in (trans)boundary rivers. Norway and Finland are parties to the CBD, which was signed on June 5, 1993, and entered into force on December 12, 1993. ${ }^{18}$ Among the objectives stated in Article 1, "the conservation of biological diversity" and "the sustainable use of its components" are important for management of salmon. Article 2 defines "biological diversity" as follows:

The variability among living organisms from all sources including, inter alia, terrestrial, marine and other aquatic ecosystems and the ecological complexes of which they are part; this includes diversity within species, between species and of ecosystems.

Thus, wild salmon stocks are covered by the CBD.

When it comes to the jurisdictional scope of CBD, Article 4(a) states that the provisions of the Convention apply, in the case of components of biological diversity, "in areas within the limits of its national jurisdiction." Unlike Article 66(3) of the LOSC, which apply to "waters", the CBD in this regard applies to components in "areas", and thus, Article 4(a) must cover rivers, watercourses and lakes. Consequently, Norway and Finland are obliged to implement the relevant measures deriving from the Convention.

As to the more specific relevance of the CBD for management of salmon stocks, there are various obligations applicable to the Contracting Parties. Article 6 imposes some general measures for conservation and sustainable use: the parties shall, in accordance with their particular conditions and capabilities, develop national strategies, plans or programs for the conservation and sustainable use of biological diversity. Secondly, they shall integrate, as far as possible and as appropriate, the conservation and sustainable use of biological diversity into relevant sectoral or cross-sectoral plans, programs and policies. The latter may apply to national authorities with regard to implementing wild salmon considerations in aquaculture management. Other obligations the CBD imposes on the national level include identification and monitoring of components of biological diversity, ${ }^{19}$ in-situ conservation ${ }^{20}$ supplemented with ex-situ conservation, ${ }^{21}$ and adoption of measures relating to the use of 


\section{Irene Vanja Dahl}

biological resources to avoid or minimize adverse impacts on biological diversity. ${ }^{22}$ Notably, the CBD in Article 5, unlike the LOSC, contains a duty to cooperate:

Each Contracting Party shall, as far as possible and as appropriate, cooperate with other Contracting Parties, directly or, where appropriate, through competent international organizations, in respect of areas beyond national jurisdiction and on other matters of mutual interest, for the conservation and sustainable use of biological diversity.

This Article has several implications for management of transboundary salmon stocks. Firstly, it is related to LOSC Article 66(5), according to which the state of origin and other states fishing the anadromous stocks shall make arrangements concerning conservation, where appropriate, through regional organizations. In the following section, I elaborate on the significance of the relevant international organization, the North Atlantic Salmon Conservation Organization (NASCO). However, it is the second implication that seems more significant as regards cooperation on shared salmon stocks: the Contracting Parties concerned shall cooperate "on matters of mutual interest, for the conservation and sustainable use of biological diversity."

Clearly, the transboundary anadromous stocks and various aspects concerning management of the stocks should be regarded as "matters of mutual interest." Hence, the duty of Norway and Finland to cooperate most likely derives from CBD Article 5. However, as each state is obliged to cooperate "as far as possible and as appropriate," the Article's character of obligation is weakened. The potential of this form of cooperation is described as "only (...) as strong as the weakest jurisdiction within the collaboration area, and (...) vulnerable to non-participation by some states." ${ }^{23}$ In addition, the content of such cooperation is quite vague: the duty applies to "matters of mutual interest."

However, CBD Article 5 and the duty to cooperate on matters of mutual interest should be viewed in the context of LOSC Article 66(1), according to which the states of origin shall have primary interest in and responsibility for the stocks. Such primary interest and responsibility underpin the interpretation that anadromous stocks in shared rivers are covered by the term "matters of mutual interest", and hence fall under the duty to cooperate.

Article $8(j)$ of CBD is also relevant for the topic of this article. When it comes to in-situ conservation, the obligation on the Contracting Parties, as far as possible and appropriate, among other things and subject to national legislation, is to:

respect, preserve and maintain knowledge, innovations and practices of indigenous and local communities embodying traditional lifestyles relevant for the conservation and sustainable use of biological diversity and promote their wider application with the approval and involvement of the holders of such knowledge, innovations and practices.

As the river is subject to traditional Sami salmon fishing both on the Finnish and Norwegian side, this obligation should be implemented in the bilateral cooperation as a "matter of mutual interest", according to Article 5 of CBD. 


\subsection{The Convention for the Conservation of Salmon in the North Atlantic Ocean (NASCO Convention)}

A duty to conserve the salmon in the Tana River may also follow from the Convention for the Conservation of Salmon in the North Atlantic Ocean (NASCO Convention). The NASCO Convention was adopted in Reykjavik in January 1982, and entered into force on October 1, 1983, following ratification by six parties: Canada, Denmark in respect of the Faroe Islands, the European Economic Community (later the EU), Iceland, the USA, and Norway. ${ }^{24}$ Finland acceded to the Convention in April 1985; since December 31, 1995, its representation in the North Atlantic Salmon Conservation Organization (NASCO) has been through the EU. ${ }^{25}$ The USSR acceded to the Convention in September 1986; its obligations were assumed by the Russian Federation in January 1992. ${ }^{26}$

The text of the NASCO Convention is published in the NASCO Handbook of Basic Texts. ${ }^{27}$ According to Article 1(1), the Convention applies to the salmon stocks which migrate beyond areas of fisheries jurisdiction of coastal states of the Atlantic Ocean north of $36^{\circ} \mathrm{N}$ latitude throughout their migratory range. Hence, the Convention is applicable to the salmon stocks discussed in this article. As to geographical scope, the Convention contains a multipart scheme. Firstly, CBD Article 2 lays down a ban on fishing of salmon beyond the areas of fisheries jurisdiction of coastal states. As to areas within the fisheries jurisdiction of coastal states, it generally prohibits fishing beyond 12 nautical miles from the baselines.

For the "conservation, restoration, enhancement and rational management of salmon stocks, ${ }^{\prime 28}$ the Convention establishes the North Atlantic Salmon Conservation Organization (NASCO) ${ }^{29}$ It is to contribute, through consultation and cooperation, to the above-mentioned issues, taking into account the best scientific evidence available.

In addition to a Council and a Secretariat, NASCO consists of three Regional Commissions: for North America, for West Greenland, and for the North-East Atlantic (NEAC).$^{30}$ It is the latter that will be analyzed in this article. The members of NEAC are Denmark (in respect of the Faroe Islands and Greenland), the EU, Norway, and the Russian Federation. The area of NEAC is "maritime waters east of the line referred to in subparagraph (b)": "a line drawn along $44^{\circ} \mathrm{W}$ longitude south to $59^{\circ} \mathrm{N}$ latitude, thence due east to $42^{\circ} \mathrm{W}$ longitude and thence due south." Hence, the maritime waters of Norway and Finland are subject to the area of NEAC. As the wording specifies "maritime areas," rivers and watercourses would not seem to be covered. However, it may be argued that the objective of NASCO, "conservation and rational management of salmon stocks," could be undermined if the measures were not to apply to salmon rivers.

Article 8 of the Convention prescribes the functions of NEAC with regard to its area:

(a) to provide a forum for consultation and co-operation among the members concerning the conservation, restoration enhancement and rational management of salmon stocks subject to this Convention. 


\section{Irene Vanja Dahl}

(b) to propose regulatory measures for fishing in the area of fisheries jurisdiction of a member of salmon originating in the rivers of other Parties; and

(c) to make recommendations to the Council concerning the undertaking of scientific research.

In cases where salmon stocks in the above-mentioned rivers of Norway and Finland migrate into areas of fisheries jurisdiction of other NASCO members, subparagraph (b) is relevant. As the main focus of this article is on cooperation among states of origin, it should be noted that subparagraph (a) provides a forum for cooperation on conservation of salmon stocks. As to geographical scope, the wording does not exclude cooperation regarding rivers. This view is supported by Article 9 of the Convention, from which the functions of NEAC derive: NEAC shall, inter alia, take into account the efforts of states of origin to implement and enforce measures for the conservation, restoration, enhancement and rational management of salmon stocks in their rivers and areas of fisheries jurisdiction (cf. Art. 9(c)), and the relative effects of harvesting salmon at various stages of their migration routes (cf. Art. 9(d)).

However, although NEAC "shall" take these factors into account, its significance for river management seems rather vague. The Convention does not state any clear obligation on states of origin to cooperate regarding salmon management and conservation in the rivers concerned-however, it does not prohibit such cooperation within the framework of NEAC. Although NEAC seems to offer a forum for cooperation on conservation on salmon, practical cooperation appears quite limited. On the NASCO home page, NEAC has its own webpage, where it is stated that the only regulatory measures the Commission has agreed upon involve Faroese salmon fisheries. ${ }^{31}$

However, NASCO as such has addressed a wide range of issues, including management of salmon fisheries by states of origin, habitat protection and restoration, and aquaculture and related activities. ${ }^{32}$ Here we focus on bilateral cooperation.

\subsection{The Indigenous and Tribal Peoples Convention, 1989 (No. 169)}

Hitherto, the article has focused on the perspective of salmon conservation through bilateral cooperation between Norway and Finland. Now, we turn to the indigenous people's perspective, which also applies to these states.

The Indigenous and Tribal Peoples Convention, 1989 (No. 169) is an International Labour Organization Convention, also known as ILO-convention 169 (hereafter: ILO 169) which was adopted on June 27,1989 , and entered into force on June 20, $1991 .{ }^{33}$ ILO 169 is the only international convention dealing especially with indigenous peoples' rights. Norway ratified ILO 169 on June 20, 1990. Finland has not ratified it, which is probably the reason why the Convention is not included on the list of relevant conventions in the Preamble of the Tana Agreement. However, some of the provisions of ILO 169, e.g. Article 8, are considered as general principles of international law. ${ }^{34}$ ILO 169 is undoubtedly binding on the Norwegian authorities 
when it comes to the Sami people's statutory rights deriving from the Convention. This is supported by the Norwegian 2014 act on the right to fishing in the Tana Watercourse (hereafter: the Tana Act), ${ }^{35}$ which in section 3 states that the act is subject to ILO 169.

The article will discuss whether the Tana Agreement complies with ILO 169 when it comes to the negotiation process leading to the Agreement, and the obligation of the Norwegian state to safeguard the Sami people's right to natural resources.

It should be mentioned that in the Preamble to the Tana Agreement, Norway and Finland refer to Article 27 of the International Covenant on Civil and Political Rights (CCPR) (1966) and the United Nations Declaration on the Rights of Indigenous Peoples (UNDRIP). Some of the discussions in section 4.2.7 may be relevant for analysis of the Tana Agreement's relation to CCPR and the protection of the Sami people's right to enjoy their own culture. As regards UNDRIP, both Norway and Finland have endorsed it by signature. However, as a UN Declaration UNDRIP is not binding as a treaty, but it might be binding as international customary law. CCRP and UNDRIP will not be further covered in this article.

\section{Regional co-operation within NASCO}

\subsection{Introduction}

Various measures relevant for salmon management in Norway and Finland have been developed within the framework of NASCO-but are they binding on the parties? Article 13 of the NASCO Convention contains a procedure whereupon measures become binding. However, this procedure applies to "regulatory measures proposed by a Commission"- the NEAC. On the other hand, the parties may, as autonomous states, agree upon binding measures. In other cases, NASCO measures may be characterized as guidelines or recommendations.

\subsection{Agreement on Adoption of a Precautionary Approach (AAPA)}

In 1998, NASCO and its contracting parties signed the binding Agreement on Adoption of a Precautionary Approach (hereafter: AAPA).$^{36}$ According to AAPA Article 1, the precautionary approach (PA) is applicable to the conservation, management and exploitation of salmon in order to protect the resource and preserve the environment in which it lives; moreover:

NASCO and its Contracting Parties should be more cautious when information is uncertain, unreliable or inadequate. The absence of adequate scientific information should not be used as a reason for postponing or failing to take conservation and management measures.

As this is the core element of the PA generally in international law, it is quite unusual for an international agreement that contains an article on the approach to elaborate further on it. However, AAPA Article 2 (a-e) lists five requirements that derive from the approach, among other things: 


\section{Irene Vanja Dahl}

- consideration of the needs of future generations and avoidance of changes that are not potentially reversible;

- priority to be given to conserving the productive capacity of the resource where the likely impact of resource use is uncertain;

- appropriate placement of the burden of proof by adhering to the above requirements.

Further, as Article 1(3) specifies that PA application should involve all parties "concerned with salmon conservation, management and exploitation," Norway and Finland have a special duty to implement it.

But, are states of origin of transboundary stocks obliged to apply the approach in their bilateral cooperation on conservation and management? Some elements in the AAPA would seem to indicate this. Firstly, under Article 4, the contracting parties commit to apply the approach to "the entire range of their salmon conservation and management activities;" and the AAPA specifies that application of the approach will concern the "management of North Atlantic salmon fisheries." Further, it follows from Article 5 that NASCO and its contracting parties are to apply the approach to "fresh-water habitat issues." Thus, Norway and Finland are to apply the PA to their salmon rivers-individually, but they should also apply it through cooperation. Otherwise, measures applicable in only one state might undermine conservation of the total stocks.

As noted, it is questionable if salmon rivers are covered by the NASCO Convention area. However, the objective of promoting the diversity and abundance of the salmon stocks may be severely weakened if it does not apply to rivers. Additional support to application of the PA to bilateral cooperation is found in Article 7, which lists various factors required, as a minimum, for application of the approach, as an integrated process. For states of origin with transboundary stocks, an expedient forum is bilateral cooperation. This applies to all the factors listed, but especially to the following subparagraphs:

c) the prior identification of undesirable outcomes including the failure to achieve conservation limits (biological factors) and instability in the catches (socioeconomic factors);

f) assessment of the effectiveness of management actions in all salmon fisheries;

g) stock rebuilding programs (including, as appropriate, habitat improvement, stock enhancement and fishery management actions) be developed for stocks that are below their conservation limits.

To summarize: the AAPA is binding on Norway and Finland. The precautionary approach contains certain requirements, such as consideration of the needs of future generations and avoidance of changes that are not potentially reversible. However, the AAPA does not impose any duty on states of origin to cooperate on the conservation of shared salmon stocks. On the other hand, the AAPA's stated objective and 
elaboration clearly indicate that bilateral cooperation is a suitable way of implementing the PA to shared salmon stocks. They clearly should apply it at the bilateral level.

\subsection{Protection and Restoration of Atlantic Salmon Habitat \\ 3.3.1 Introduction}

One of the objectives of the PA-protection of the environments in which the salmon live- has been further elaborated. In 2001, the NASCO Plan of Action for the Application of the Precautionary Approach to the Protection and Restoration of Atlantic Salmon Habitat (hereafter: the Plan/the Habitat Plan of Action) was adopted. ${ }^{37}$ The NASCO Contracting Parties have not acceded to the Plan, so it is not binding on them. However, the Plan "is intended to be used as a framework by the appropriate jurisdictions, national, regional or local, that have responsibility for activities involving salmon habitat." ${ }^{38}$ As bilateral Norwegian/Finnish cooperation structures are based on national jurisdictions with habitat responsibilities, the Plan is applicable to such cooperation. The Plan "lays down the guiding principles and the means to implement the PA with regard to habitat and calls for the development of national salmon habitat protection and restoration plans." ${ }^{\prime 39}$ As the habitat of the salmon stocks in the Tana Watercourse rivers is of a distinctly transboundary nature, it is obvious that protection and restoration plans should involve bilateral cooperation.

In the case of a border river, the salmon's "environments in which it lives" may be regarded as one comprehensive habitat. If the states of origin do not cooperate on protection and restoration, this may pose a risk to the overall objective of NASCO: "to conserve enhance, restore, and rationally manage salmon stocks." ${ }^{40}$ According to the Preamble to the Plan, this objective "can only be achieved if habitat is also conserved and restored. It is also clear that over the last 150 years much salmon habitat has been lost and this must be a major contributing factor to the decline in wild salmon stocks." This gives further encouragement to bilateral cooperation.

Without cooperation, effective implementation of what is described as "an important step"- - to quantify existing habitat and, if possible, the extent of loss and degraded habitat" ${ }^{41}$ - would be highly challenging. Further, as also noted in the Preamble, the Plan "aims to describe all of the necessary elements to provide a consistent, rational approach to protection and restoration of habitat under a precautionary regime and a reporting procedure to enable progress to be monitored." In the following, some of these elements are analyzed, with a focus on their relevance for bilateral salmon cooperation regimes.

\subsubsection{Guiding Principles}

\section{Inventories}

The Plan establishes a list of "guiding principles" for maintaining or increasing the current productive capacity of Atlantic salmon habitats. ${ }^{42}$ First on the list is "establishing inventories of rivers for the protection and restoration of salmon habitat." 


\section{Irene Vanja Dahl}

At first sight, this measure relates to a state's domestic management of each salmon river. However, some elements deriving from Annex 2 to the Plan-like the use of an inventory of salmon rivers in the protection and restoration of salmon habitat-will require cooperation among the states of origin in the case of (trans)boundary rivers.

Firstly, this applies to the compilation of an inventory, which entails amassing large amounts of data on type of river, geology, topography, species composition and special factors (e.g. sensitivity), as well as NASCO's categorization of salmon stock factors (lost, maintained, restored). Secondly, this applies to the Annex's requirement of recording information necessary to assess the extent of impacts or habitat degradation. The final element here is the recording of data on habitat impact, i.e. activity causing impact. In addition to establishing inventories, the NASCO Contracting Parties shall regularly report on and update these inventories. Additional requirements that involve bilateral cooperation include identifying and designating priority/key habitats for improvement and sharing and exchanging information on habitat issues and best-management practices.

\section{Habitat protection and restoration plan}

The second principle mentioned in the Plan concerns establishing comprehensive salmon habitat protection and restoration plans aimed, inter alia, at identifying potential risks to productive capacity, and developing procedures for implementation of corrective measures, taking into account other biological factors that affect the productive capacity of Atlantic salmon populations.

The biennial invasion of pink salmon in the rivers of the Tana Watercourse makes clear the importance of this guideline. The pink (or humpback) salmon (Oncorhynchus gorbuscha) is a North Pacific salmon stock that entered rivers in northern Norway in the 1960s, after being released on the Kola Peninsula. ${ }^{43}$ It has a two-year lifecycle; both males and females die shortly after spawning in the autumn. After hatching the following spring, the salmon fry migrate to the sea, to spend the following year feeding on crustaceans and fish. During the second summer, they return to freshwater to spawn and complete their lifecycle. The pink salmon on the Kola Peninsula spawn in odd-numbered years. ${ }^{44}$

The use of the term "invasion" requires clarification. In January 2020, the Norwegian Scientific Committee for Food and Environment (VKM) assessed the impact of pink salmon on Norwegian rivers, noting 2017 as a year when the numbers of pink salmon surged in the rivers of eastern Finnmark. ${ }^{45}$ In 2019, this area expanded to rivers in western Finnmark. Of the total reported catch of pink salmon in Norwegian rivers in the ordinary season of 2019 , of 10.5 tons, 9.6 tons were caught in Finnmark. ${ }^{46}$ Given the two-year cycles, an influx of pink salmon invasion in 2021 seems likely. ${ }^{47}$ Pink salmon spawning habitat requirements are generally like those of native salmonids, but spawning occurs earlier than the native salmonids. However, observations in 2019 indicate a possible overlap with native salmonids in September. 
Moreover, pink salmon juveniles impact native salmonid juveniles through competition for food and space, and invertebrate fauna through predation. ${ }^{48}$

To what degree, then, does the pink salmon represent a risk to the native salmon populations in these rivers? The above-mentioned VKM report took up these questions. ${ }^{49}$ Before turning to some of the most significant risk factors, we should note that the impact of pink salmon depends on their abundance: high abundance may have serious repercussions, whereas low numbers may be of little consequence: ${ }^{50}$

An increasing abundance of reproducing pink salmon will likely present hazards to biodiversity and river ecosystems. Establishment of reproducing pink salmon over larger areas in Norway will probably increase the regularity of abundant returns to Norwegian waters. The invertebrate fauna will be negatively affected where large numbers of pink salmon juveniles use it as a food source. This is more likely in long than in short rivers. The freshwater pearl mussel, Margaritifera margaritifera, may be particularly vulnerable, as it has a larval stage in juvenile Atlantic salmon or brown trout, but cannot use pink salmon as a host. ${ }^{51}$

The more specific risk factors concern among other things: 1) pathogens and parasites, 2) competition for food, space and spawning grounds, and 3) interaction with climate change.

\section{Pathogens and parasites}

Pathogens include viruses, bacteria, and parasites (eukaryotic organisms). Little is known about the susceptibility of pink salmon to viral pathogens. Of 11 viral pathogens assessed, only three or four are known to infect pink salmon..$^{52}$ The Norwegian Scientific Committee for Food and Environment (VKM) assessed the potential negative impact on biodiversity in the marine ecosystem and productivity of native salmonid species as "low to minimal" for all viral and bacterial pathogens considered, apart from Renibacterium salmoninarum and viral haemorrhagic septicaemia virus, for which the risks were assessed as "moderate." Regarding parasites, the VKM found that these might represent "a major hazard to salmonids." After assessing three groups of parasites, the VKM concluded: "the abundance and spread of some of these parasites may be affected by the incursion of pink salmon."

\section{Competition for food, space and spawning grounds}

The VKM found that interactions between pink salmon and native salmonids may occur through competition for food or for space in the river before spawning and on the spawning grounds. ${ }^{53}$ When feeding in the river, pink salmon fry ingest the same prey as native salmonid fry. In addition, high densities of pink salmon fry may influence the native salmonid fry's ability to establish territories. On the other hand, pink salmon fry may serve as food for older life stages of native salmonids. As regards spawning grounds, the competition may be less of a problem, as pink salmon spawn earlier in the autumn than do Atlantic salmon. However, the VKM noted the 


\section{Irene Vanja Dahl}

temporal overlap between Arctic char (Salvelinus alpinus) and pink salmon spawning in northern Norway, and a possible overlap with early-spawning brown trout (Salmo trutta). In addition, high numbers of pink salmon may have a crowding effect on native salmonids before the actual spawning time.

\section{Interaction with climate change}

Further, the VKM report found that, under the emerging conditions of shifting climate, pink salmon may come to spawn and produce offspring in all rivers along the Norwegian coast. ${ }^{54}$ Regarding the Tana River and other rivers in eastern Finnmark, the report noted that regular occurrence of the odd-year strain has thus far been seen only in rivers in this area where self-sustaining populations may have been established. ${ }^{55}$ Further, the rising sea surface temperatures and reduced ice cover over the past 20 years may benefit pink salmon in the ocean, and be one reason for the increasing numbers of pink salmon in northwest Russian and Norwegian waters. Although the effects of rapid climate change are difficult to predict, "it is likely that a climate warming over the next 50 years will facilitate the establishment of circumpolar pink salmon populations in Arctic rivers. ${ }^{36}$ This risk factor would then affect Norway, Finland and Russia.

In its conclusions, the VKM mentions a specific, feasible measure for reducing the impact of pink salmon in rivers: targeted fishing adapted to local conditions. ${ }^{57}$ Experience from 2017 and 2019 has shown this to be effective for decreasing or even eliminating the threat of pink salmon to native salmonids and biodiversity. In order to reduce the number of pink salmon, the report notes the need for "concerted action on a regional, national and international level." ${ }^{58}$ This is of special relevance for Norway and Finland, as the Habitat Plan of Action calls on each relevant jurisdiction to "co-ordinate Salmon Habitat Protection and Restorations Plans with regard to transboundary issues." ${ }^{.9}$

\subsection{Guidelines for the Management of Salmon Fisheries}

In 2009, NASCO adopted Guidelines for the Management of Salmon Fisheries (hereafter: Management Guidelines) ${ }^{60}$ The document is not a binding agreement, but is "intended to serve as guidance to the NASCO Parties for the management of wild salmon fisheries subject to their national legislation." ${ }^{61}$ Whereas NASCO stresses that it cannot be prescriptive about specific approaches for managing homewater salmon fisheries, it adds that the Management Guidelines "should be applied in all jurisdictions" in order to protect the abundance and diversity of salmon stocks. ${ }^{62}$

Several of the Management Guidelines lend themselves to bilateral-level implementation. Among other things, there is a recommendation to collect various types of information on a routine basis, applicable to recreational, commercial, subsistence and scientific fisheries. ${ }^{63}$ The information is to include records of fishing activity-e.g. 
license numbers and catch statistics. As the Management Guidelines aim to protect the abundance and diversity of entire salmon stocks, assembling this information should involve transboundary cooperation.

In addition, the Management Guidelines recommend that managers be able to close fisheries and regulate fishing effort and/or harvests. ${ }^{64}$ Also use of this measure should be coordinated bilaterally. Obviously, the measure applies to native salmon stocks. However, in view of the aim to maintain the abundance and diversity of such stocks, it could be regarded as a recommendation to coordinate, for instance, extinction fishing of pink salmon. This is supported by the guideline that managers should be able to respond with appropriate speed to changes in individual stock status, and be able to implement pre-agreed measures to adjust harvest levels or fishing effort in-season to take account of actual run sizes or "environmental conditions." ${ }^{65}$

The possible impact of pink salmon may be seen as an environmental condition which Norway and Finland should deal with as a transboundary issue. They could agree on measures aimed, for instance, at reducing the amount of pink salmon in case of an invasion. If the states involved implement bilaterally agreed measures, these should be followed up by agreed enforcement measures, as stated in the Management Guidelines, after which managers should be able to enforce the measures that are in place to regulate fishing activity and minimize unreported catches. ${ }^{66}$

\subsection{Guidelines on the Use of Stock Rebuilding Programs \\ 3.5.1 Introduction}

The NASCO Contracting Parties have agreed to apply a precautionary approach, which requires, inter alia:

- all salmon stocks in the NASCO Convention Area are to be maintained above their conservation limits (CLs) by use of management targets, and

- stock rebuilding programs are to be developed for stocks that are below their CLs.

In order to provide guidance on the process of establishing a Stock Rebuilding Program (SRP) of a salmon stock and the contents of such a plan, NASCO in 2004 adopted a set of guidelines on the use of stock rebuilding programs (hereafter: SRP Guidelines). ${ }^{67}$ Both Norway and Finland have applicable schemes for meeting the obligation to apply the precautionary approach.

An SRP is "an array of management measures, possibly including habitat restoration/improvement, exploitation control and stocking, which is designed to restore a salmon stock above its conservation limit." 68

The SRP Guidelines contain seven recommendations, elaborated in further detail in the scheme. In the following sections, three recommendations with special significance for states of origin to transboundary stocks will be examined. 


\section{Irene Vanja Dahl}

\subsubsection{Evaluate the status of the stock}

This guideline refers to the Conservation Limits (CLs), ${ }^{69}$ and the NASCO recommendation that SRPs be developed for all stocks that fail to exceed their CLs. The message in the SRP Guidelines is that assessing the status of the stock requires more than simply determining whether the escapement has fallen below the CL, and that a range of other factors will influence management decisions on the nature and extent of the SRP. Among these factors is the nature of CL failure and how to deal with it. Moreover, the further that a stock falls below its CL and the number of years this happens, the greater the probable need for management action. "Ideally, managers and stakeholders should agree in advance upon the failure criteria that will trigger certain management actions." 70 The relevant originating states, as "managers," have a responsibility to address this issue.

\subsubsection{Evaluate causes of stock decline and threats to stock}

The core element in the SRP Guidelines for evaluating the causes of stock decline and threats to stock is that proposals for remedial measures should be developed on the basis of a full assessment of the pressures faced by the stock. ${ }^{71}$ The SRP Guidelines note reduced production and/or increased mortality, resulting from natural or anthropogenic factors, as causes for stocks falling below their CLs. Even though the exact reasons for the stock decline may be unknown, the parties should describe and evaluate possible causes and potential threats. The guidelines suggest and describe several types of factors that may be considered: habitat degradation, species interactions, exploitation, and differential effects on stock components. With transboundary stocks, all these factors may be assessed more effectively and comprehensively at the bilateral level, than exclusively at the domestic level.

\subsubsection{Plan and prioritize management actions}

The next recommended step, after having identified the potential problems and threats, is to develop a program of management actions to address the challenges, and here, "[e]fforts should be made to ensure all activities are consistent with the Precautionary Approach." 72 This should also be addressed bilaterally in the case of transboundary salmon stocks. For instance, it follows from the guideline that where several problems/threats have been identified, priorities must be set regarding proposed actions to assist in planning the funding of the conservation and restoration program.

\section{Bilateral cooperation}

\subsection{Introduction}

As noted, the boundary Tana River has long been attractive for fishing salmon. According to LOSC Article 66, both Norway and Finland are to be regarded as 
"states of origin," with primary interest in and responsibility for the salmon stocks. However, the LOSC does not contain any provisions for cooperation on transboundary salmon stocks. On the other hand, CBD Article 5 obliges the parties to cooperate on matters of mutual interest for the conservation and sustainable use of biological diversity. Regarding primary responsibility for salmon stocks, according to LOSC Article 66, the obligation to cooperate on conservation and management of transboundary salmon stocks may be deduced.

According to CBD Article 5, cooperation on matters of mutual interest shall take place "directly or, where appropriate, through competent international organizations." As Contracting Parties to the NASCO Convention, Norway and Finland cooperate with the other Parties within the frames of NASCO. The NASCO regime, however, has few provisions on salmon conservation and management concerning border rivers. A notable exception is the AAPA, ${ }^{73}$ which commits both Norway and Finland to adopt and apply a precautionary approach to the conservation and management of salmon stocks. The AAPA does not contain specific provisions on bilateral cooperation: various aspects deriving from the Agreement itself and the NASCO instruments serve as guidelines for implementation, e.g. the Guidelines for Protection and Restoration of Atlantic Salmon Habitat, Guidelines for the Management of Salmon Fisheries and Guidelines on the Use of Stock Rebuilding Programs. In order to meet AAPA's aim that all salmon stocks in the NASCO Convention Area are to be maintained above their conservation limits (CLs), a certain level of bilateral cooperation as regards transboundary stocks appears necessary. The Habitat Plan of Action supports this, as it recommends each relevant jurisdiction to coordinate Salmon Habitat Protection and Restorations Plans with regard to "transboundary issues." ${ }^{\prime 4}$ Hence, Norway and Finland are clearly required to deal with the conservation and management of their shared salmon stocks at the bilateral level.

\subsection{The Tana River}

\subsubsection{Introduction}

Salmon fishing in the Tana Watercourse has been regulated in bilateral agreements between Norway and Finland ever since $1873 .{ }^{75}$ The currently applicable agreement (the Tana Agreement) was adopted September 30, 2016, ${ }^{76}$ replacing the 1989 agreement on common fisheries regulations in the Tana River. Both the Norwegian (Stortinget) ${ }^{77}$ and the Finnish (Eduskunta Riksdagen) ${ }^{78}$ parliaments adopted the Tana Agreement in March 2017. In the Preamble, Norway and Finland emphasize their responsibility according to international conventions and the need to protect the fish stocks in the Tana Watercourse through expedient regulation of the fisheries, based on the precautionary principle. Hence, they recognize some of the abovementioned general principles regarding salmon conservation and management. Their responsibility is strengthened by the Preamble reference to Article 66 of LOSC, the CBD, the NASCO Convention, and the guidelines on management of salmon 


\section{Irene Vanja Dahl}

fisheries adopted on the basis of that Convention. In addition, the Preamble refers to Article 27 of the International Covenant on Civil and Political Rights (CCPR) and the United Nations Declaration on the Rights of Indigenous Peoples (UNDRIP). The rights of the Sami people to natural resources is a relevant issue for both Norway and Finland.

Further, in the Preamble, Norway and Finland stress the need for information exchange and cooperation on the exploitation and management of shared natural resources.

Their recognition of the Preamble to the Tana Agreement indicates that they intend to implement the obligations and guidelines deriving from international law. Let us now examine the degree to which Norway and Finland have implemented these provisions and what structures they have established in order to operationalize them.

\subsubsection{Salmon management}

The Tana Agreement contains several provisions on common salmon management, significantly updated according to current international law. The objective is to contribute to ecological, economic, and socially sustainable management of the salmon stocks of the Tana Watercourse, in order to exploit the capacity for salmon production and secure the diversity of the salmon stocks. ${ }^{79}$ Norway and Finland are to follow up the objective by adopting a management plan, ${ }^{80}$ to serve as the foundation for all regulations regarding salmon fishing. This plan is to be based on the best available knowledge on the salmon stocks and apply the precautionary principle.

The provisions on the objective and contents of the plan are largely in line with the above-mentioned guidelines deriving from the NASCO instruments. ${ }^{81}$ Together, Norway and Finland are to design a management plan for the salmon stocks in the Tana River in order to secure biodiversity and sustainable use. The plan shall contain the following elements: 1) information on the condition of the stocks and their habitat, 2) information on fishing, 3) conservation limits (CLs) for each salmon stock, 4) suggested management measures, and 5) suggested measures for rebuilding if stocks fall below the CLs. ${ }^{82}$ Further, if one or more stocks should fall below the CLs, rebuilding plans shall be included in the management plan. The overall impression of the bilateral management plan is that it meets the guidelines set out in the Habitat Plan of Action, ${ }^{83}$ the Management Guidelines ${ }^{84}$ and guidelines for Stock Rebuilding Programs. ${ }^{85}$

NASCO considers regulation of fishing effort through control of the number of fish caught or the amount and type of fishing gear used to be expedient measures for maintaining the abundance and diversity of all river stocks. ${ }^{86}$ This measure is addressed in the Tana Agreement. ${ }^{87}$ The parties are obliged to have common fishing regulations applicable to the border length of the river. Such regulations are adopted as Annex 2 to the Tana Agreement, and constitute an integral part of it. The fishing regulations are quite detailed, and are to serve in further implementation of the 
NASCO recommendations. The regulations contain provisions as to fishing licenses, gear, seasons and hours, mode and release, protection from biological impacts, and pre-agreed measures if the status of a stock is found to deviate from the management plan. The scheme in Annex 2 supports the impression that the parties largely comply with NASCO regulations.

We now turn to some issues relating to the Tana River in particular.

\subsubsection{Management of pink salmon}

A new invasion of pink salmon is predicted in 2021. Does the Tana Agreement contain provisions that can help to reduce the impact? Norway and Finland have addressed the question of pink salmon in Articles 30 and 31 of Annex 2 of the Agreement. It follows from Article 31, in the section dealing with protection from biological impacts, that pink salmon is regulated as a foreign species, to be killed immediately if caught. Article 30 deals with notification of catches to the digital registry for the Tana Watercourses. Pink salmon is one of the listed species of which catches shall be reported. These are the only provisions in the Tana Agreement dealing explicitly with pink salmon. However, it follows from Article 15(1) of the Agreement that the parties shall implement measures necessary in order to protect fish stocks from the introduction of foreign species. As mentioned, extinction fishing of pink salmon is one recommended measure - and one that Norway and Finland may be obliged to implement. As pink salmon may become a growing risk to native salmon stocks in the future, the parties should monitor any invasion in 2021, step up their research efforts, and consider including more intrusive regulations in the Tana Agreement.

\subsubsection{Habitat management}

The Tana Agreement does not contain any specific provisions on habitat conservation and restoration. However, the Agreement presupposes habitat management of some kind. The objective of the Agreement - to contribute to sustainable management of the salmon stocks, in order to exploit the watercourse's capacity for salmon production and secure the diversity of the fish stocks - can hardly be achieved without parallel sustainable management of the habitat. The underlying reasons for the low focus on habitat are most likely the causes of the decrease in the stocks: overexploitation. ${ }^{88}$ Habitat conditions in the Tana River are described as natural fluctuations of the stocks, as a result of e.g. environmental variation and predation in the sea and rivers. ${ }^{89}$ Thus, the focus of the Agreement is on reducing the fishing pressure. ${ }^{90}$ However, habitat conditions are subject to Chapter 5 of the Agreement: Protection of the fish stocks. According to these provisions, the parties are obliged, separately and through cooperation, to implement measures for monitoring, maintaining and if necessary improving the water quality of the Tana Watercourse. ${ }^{91}$ Further, they undertake to prevent discarding of water and cleaning of fish caught in other watercourses and, separately or through cooperation, to implement mitigation measures 


\section{Irene Vanja Dahl}

in cases of threats from pollution or other environmental impacts. ${ }^{92}$ To a certain extent, the Tana Agreement reflects guidelines set out in the Habitat Plan of Action, but the focus is clearly on reducing fishing pressure. However, the current healthy condition of the habitat may change. Consequently, the Agreement needs mechanisms for dealing effectively with potential habitat risks.

\subsubsection{Management structures}

Effective implementation of the provisions of the Tana Agreement presupposes a functioning management structure. Norway and Finland may of course implement domestic measures on their own. However, the above-mentioned reasons for bilateral cooperation also apply to bilateral mechanisms for implementation of agreed measures. In order to achieve the objectives of the Tana Agreement and the guidelines deriving from international law, a certain level of bilateral implementation is expedient as regards shared salmon stocks. In the Tana Agreement, Norway and Finland have agreed upon some common implementation mechanisms. Firstly, a joint monitoring and research group consisting of two members from each state shall be established. ${ }^{93}$ The group shall conduct the parties' general obligation to monitor and research fish stocks in the Tana Watercourses, ${ }^{94}$ and annually assess the effects of the fishing regulations of the Agreement. ${ }^{95}$ Such assessment is to be conducted in association with the responsible authorities of each state. It must be assumed that the joint monitoring and research group shall also implement the parties' general obligation to cooperate on monitoring and research on fish stocks in the Tana Watercourse ${ }^{96}$ In particular, such research should serve as a basis for an evaluation of the management plan and fishing regulations, according to Articles 4 and 7 of the Tana Agreement.

As the joint monitoring and research group shall assess the effects of the Agreement's fishing regulations "on the basis of the best available knowledge of the salmon stocks' condition and developmental trends, ${ }^{, 97}$ the question arises as to whether traditional knowledge is covered by this provision. As mentioned in section 2.2, it follows from Article 8(1) of CBD that the parties shall respect, preserve and maintain knowledge and practices of indigenous communities relevant for the conservation and sustainable use of biological diversity and promote their wider application with the approval and involvement of the holders of such knowledge, innovations and practices. At least to a certain degree, Sami knowledge and practices are represented in the joint monitoring and research group, as "local fishing rights holders shall be involved in the work of the group." ${ }^{98}$ The mandate of the group gives effect to the implementation of traditional knowledge, as it among other things obliges the joint monitoring and research group to "integrate local and traditional knowledge of the stocks in the assessments." 99

Whereas the establishment of the joint monitoring and research group and its tasks appears to be mandatory, joint Norwegian-Finnish supervision patrols "may" control the fishing. ${ }^{100}$ Such joint controls are additional to mandatory supervision 
by the national authorities. However, the non-binding character of joint supervision may undermine effective and comprehensive monitoring of the entire river. This applies especially to a possible situation in which one of the parties gives higher priority to more financial resources to its part of the river than does the other party. Norway and Finland "may" agree on a joint plan for monitoring of fishing. ${ }^{101}$ Nevertheless, such a measure is voluntary, which strengthens the impression that fisheries control is left to the domestic level.

A third joint mechanism established by the Tana Agreement is the mandatory registry of catches. ${ }^{102}$ Fishers are obliged to report to the registry information on fishing effort and catches according to the fishing provisions in Annex 2 to the Agreement. ${ }^{103}$ This information is to serve as a basis for catch statistics, planning of management measures, monitoring and inspections, and research on fish stocks and fishing activity. All this is clearly relevant for the joint monitoring and research group, but could also be useful for other possible permanent Tana Agreement bodies, e.g. regarding planning of management measures.

Although the Agreement establishes only two permanent bodies-the monitoring and research group, and the registry of catches-it contains a provision aimed at follow-up of the Agreement. The parties' competent authorities "shall" cooperate on all matters related to the fish stocks and ecotoxicity in the Tana Watercourse. ${ }^{104}$

\subsubsection{Eligibility criteria}

Exploitation of salmon in the Tana River is mainly regulated by fishing licenses. It follows from Annex 2 to the Tana Agreement that that the following categories of fishers, as per Norwegian and Finnish regulations, may purchase a geographically specific, time-limited license (fiskekort):

\section{In Norway:}

1) Holders of fishing rights on the basis of $₫ 4$ in the Tana Act: ${ }^{105}$ farmers living less than $2 \mathrm{~km}$ from the riverbank, holding the right to fish, with all the permitted gear.

2) Holders of fishing rights on the basis of $₫ 5$ in the Tana Act: i.e. persons resident in the municipalities of Tana and Karasjok, holding the right to fish with rod or handline from land and from boat. In addition, non-resident reindeer herders enjoy the right to rod fishing when herding in the river district.

3) Persons not holding fishing rights on the basis of the Tana Act, and not permanently resident in the river valleys of the Tana Watercourse.

\section{In Finland:}

1) Holders of fishing rights on the basis of $₫ 4(1) 10$ in the Fisheries Act (379/2015), permanently resident in the river valleys of the Tana Watercourse. 


\section{Irene Vanja Dahl}

2) Holders of fishing rights on the basis of $₫ 4(1) 10$ in the Fisheries Act, not permanently resident in the river valleys of the Tana Watercourse.

3) Persons permanently resident in the river valleys of the Tana Watercourses.

4) Persons not holding fishing rights on the basis of the Fisheries Act, and not permanently resident in the river valleys of the Tana Watercourse.

The Norwegian and the Finnish eligibility criteria may seem to overlap. However, the Norwegian criteria 1 and 2 refer to local residents, whereas the Finnish criteria 1 and 2 refer to, respectively, permanent local residents holding real estate and associated fishing rights, and non-permanent residents in an equivalent position. ${ }^{106}$ Additional restrictions concern the categories of fishing licenses. ${ }^{107}$ These regulations deal with which of the categories of those eligible to obtain fishing licenses may purchase the various categories of fishing licenses, and to what kinds of fishing the various licenses apply. ${ }^{108}$ General fishing licenses for local fishers and rod-fishing licenses for local residents are seasonal. Such licenses are available only to permanent residents in the river valleys of the Tana Watercourses on the Finnish side, and in the municipalities of Tana, Karasjok and parts of Kautokeino on the Norwegian side. Licenses for boat fishing and beach fishing apply for one day and are basically intended to be sold to visitors - tourists and non-residents. The general license to locals permits fishing with all methods allowed according to the regulations, whereas the other licenses are restricted to rod fishing.

\subsubsection{Compliance with ILO 169}

After the Tana Agreement came into force, there has been discussion both in Norway and Finland related to the agreement's compliance with international law on indigenous peoples, especially ILO 169. The following section will focus on the discussion in Norway. As I will get back to, the court of first instance (Øst-Finnmark tingrett) delivered a ruling on October 9,2020, on among other things whether the process leading up to the Tana Agreement complies with Article 6 of ILO 169. ${ }^{109}$

ILO 169 is relevant for the subject of this article of several reasons. Among other things, Article 6(1) of the Convention imposes a duty on the Norwegian government to consult the Sami people concerned, through appropriate procedures and in particular through their representative institutions, e.g. the Sami Parliament (Sámediggi), "whenever consideration is being given to legislative or administrative measures which may affect them directly." As the Sami people traditionally have fished for salmon in the Tana River, the Tana Agreement, which contains a number of concrete measures regarding fishing, is likely to affect the Sami people directly. Below, I discuss whether the Sami people were sufficiently consulted in the negotiation process leading to adoption of the Tana Agreement.

In addition, according to Article 15(1) of ILO 169, the rights of the Sami people "to the natural resources pertaining to their lands shall be especially safeguarded. These rights include the right of these peoples to participate in the use, management 
and conservation of these resources." ILO 169 Article 13(2) defines the term "lands" in Articles 15 and 16 as "the concept of territories, which covers the total environment of the areas which the peoples concerned occupy or otherwise use." Consequently, rivers are covered by the term "lands." This interpretation also follows from the ILO A Manual:

The concept of land usually embraces the whole territory they use, including forests, rivers, mountains and sea, the surface as well as the sub-surface. ${ }^{110}$

The article will now discuss some of the concrete provisions in the Tana Agreement in light of the mentioned ILO 169 Articles.

\section{The negotiation process}

Were the Sami people sufficiently consulted in the negotiation process leading up to the Tana Agreement?

According to Article 6(1) of ILO 169, the Sami people shall be consulted "through appropriate procedures." It seems beyond doubt that the Sami Parliament was consulted, as consultation meetings were held respectively August 26, 2016, on the draft agreement and January 12, 2017, regarding the Ministry of Foreign Affairs' proposition to the Norwegian Parliament on the Tana Agreement. ${ }^{111}$ The question is whether these consultations meet the requirements of "appropriate procedures." The fact that consultation, according to the A Manual, is "a fundamental principle of the Convention," 112 suggests that the consultation procedures must be comprehensive to qualify as "appropriate." This is supported by the ILO A Manual, which amplifies that "before adopting any laws or administrative provisions which might affect them directly, governments must have open, frank and meaningful discussions with the peoples concerned." 113

Further criteria regarding consultation procedures derive from Article 6(2) of ILO 169. According to this provision, the consultations "shall be undertaken in good faith and in a form appropriate to the circumstances, with the objective of achieving agreement or consent to the proposed measures." For consultation to be "appropriate", the ILO A Manual stresses that "it must meet the requirements of each specific situation, and must be meaningful, sincere and transparent." ${ }^{114}$ Consequently, Article 6 of ILO 169 contains a set of criteria the Norwegian government must take into account when consulting the Sami people. Although the criteria seem to a certain degree imprecise, the overall impression is that the consultation must qualify as a "true" consultation. ${ }^{115}$ Hence, whether a concrete consultation process meet the criteria, depends on the circumstances of each specific situation.

When it comes to the negotiation process of the Tana Agreement, it has been characterized as follows:

Representatives from Sami organizations are fighting to continue their traditional practice of fishing with nets, while the government authorities want to prohibit this 


\section{Irene Vanja Dahl}

practice in order to conserve fish stocks, but paradoxically promoting sport fishing. The legal sides of the conflict deal with the fact that the state authorities failed to comply with their consultation obligations to the Sami under ILO 169 article 6, and instead negotiated bilaterally over their heads, and on that basis signed an agreement on the regulation of the salmon resources. ${ }^{116}$

This quite severe assertion deserves comment. The reference of the cited text piece is a press release from the Norwegian government, on the occasion of the government's submission of the proposition on the Tana Agreement to the Norwegian Parliament. ${ }^{117}$ However, consulting the referred website, it is difficult to find any support there for the claim that the negotiations took place "over their heads."

However, two salmon fishing organizations, consisting of a significant amount of fishing rights holders in the Tana watercourse, have brought the Tana Agreement before the courts: Laksebreveierne i Tanavassdraget SA (LBT) and Laksefiskeforeningen i Tanavassdraget (LFT). One of the questions at stake was whether the Tana agreement process complies with Article 6 of ILO 169 and the duty of consultation. LBT represents approximately 250 holders of fishing rights, entitled to fish for all species and with all the allowed fishing gear in the watercourse. LFT organizes all fishing rights holders in the watercourse, including reindeer herders eligible for salmon fishing when herding in the river district. LFT currently has approximately 80 members, and its main objective is to protect traditional local fishing rights in the Tana watercourse. On 9 October 2020, Øst-Finnmark tingrett (the court of East-Finnmark) delivered judgement in the case. ${ }^{118}$ The Norwegian state was acquitted. Among other things, the court concluded that the consultation obligation was fulfilled regarding the Sami Parliament, and that the Finnish holiday home owners' rights comply with the rights of the Sami fishers. At the present time, whether the ruling will be appealed has not yet been decided.

Let us now turn to the question of whether the aforementioned consultation meetings qualify as "appropriate procedures." During the consultation on the draft agreement on August 26, 2016, the Sami Parliament stressed the significance of local legitimacy and requested further negotiations between Norway and Finland, where local licensees would be given a more prominent role. ${ }^{119}$ To certain degree, this would seem to indicate "open, frank and meaningful" discussion. The fact that the Sami Parliament's plenary session on September 29, 2016, assessed and rejected the draft agreement, may also support the impression of real consultation, as the Sami Parliament actually discussed the draft agreement.

However, according to the Sami Parliament, the negotiation process did not comply with international law. ${ }^{120}$ The Sami Parliament has argued that, in addition to the ordinary official negotiation meetings consisting of the Finnish and the Norwegian delegations, the agreement process was characterized by frequent delegation leader meetings. In these meetings, delegates from the Finnish and Norwegian governments participated, whereas local delegates and the delegate appointed by the Sami Parliament were excluded. ${ }^{121}$ Further, the Sami Parliament has amplified that up to 
2014, the leaders of the Norwegian delegation informed the other members both in advance and after delegation leader meetings on a regular basis. However, from the end of 2015, this information procedure ceased, ${ }^{122}$ and the delegation as such was replaced by a so-called "contact group". ${ }^{123}$ According to the Sami Parliament,

it seems clear that the negotiations from this stage did not take place within the negotiation meetings consisting of the entire delegations, instead the real and substantial negotiations took place within the so-called delegation leader meetings, and thus in the absence of the Sami parliament's delegation member. ${ }^{124}$

Viewed against the obligation to consult through "appropriate procedures," the negotiation process seems somewhat questionable based on the Sami Parliament's description of the process. Firstly, one may question whether the delegation leader meetings actually facilitated the objective of achieving agreement or consent to the proposed measures in the Tana Agreement, as follows from Article 6(2) of ILO 169. If substantial negotiations took place in the absence of the Sami delegate, the potential for real influence by the Sami people (and the local right holders) on the Tana Agreement may have been undermined. The same goes for achieving consent. Secondly, the major impact the Tana Agreement has on the Sami people may strengthen the requirement that consultation procedures should be "appropriate to the circumstances."

It is questionable whether the absence of the Sami delegate during an essential phase of the agreement negotiations complies with the requirement to establish "meaningful, sincere and transparent" procedures. Hence, it is doubtful whether the Tana Agreement procedure qualifies as "true" consultation in compliance with ILO 169 Article 6(1).

\section{Safeguarding of the Sami people's rights to natural resources}

The Tana Agreement's relation to Article 15(1) of ILO 169 will be discussed from the perspective of whether the agreement's provisions on fishing restrictions comply with the obligation to safeguard the rights of the Sami people to the natural resources pertaining to their lands. According to the ILO 169 A Manual:

Use of and access to natural resources form the basis of indigenous and tribal peoples' subsistence economies. In order to ensure the survival of indigenous and tribal peoples, it is therefore necessary to protect:

1) their natural resources, and

2) their traditional practices for using, managing and conserving these resources.

The first issue to be discussed in light of Article 15(1) is whether the Tana Agreement's introduction of a new category of fishing eligibles, namely the so-called "Finnish holiday home owners", complies with the above-mentioned criteria. According to the Tana Agreement, Appendix $2 \rrbracket 2$, holders of fishing rights on the basis of 


\section{Irene Vanja Dahl}

$\S 4(1) 10$ in the Fisheries Act are not permanently resident in the river valleys of the Tana Watercourse. These people, who own property along the watercourse on the Finnish side, are usually referred to as "holiday home owners."

The Finnish holiday home owners in the river valleys of the Tana Watercourse are eligible to buy fishing licenses. Considering this right in isolation, this may not seem contrary to Article 15(1) of ILO 169. On the other hand, the Finnish holiday home owners are not protected by ILO 169. If the introduction of their rights negatively affects the Sami people's protected rights, this may result in a violation of the specific obligation to safeguard the rights of indigenous peoples deriving from Article 15(1). In order to support an effective application of Article 15(1), necessary fishing restrictions should primarily apply to other fishers than the Sami.

The objective of the Tana Agreement is to

contribute to an ecological, economic and social sustainable management of the fish stocks of the Tana Watercourse, based on best available knowledge, including traditional knowledge, in order to exploit the capacity for salmon production and secure the diversity of the fish stocks. ${ }^{125}$

As "traditional knowledge" is included in the objective clause, the interests of the Sami people seem safeguarded, at least to some degree. This impression is supported by Article 1(2) of the Tana Agreement, according to which fishing based on local, traditional culture, especially shall be safeguarded when conserving measures are adopted and applied. Thus, with regard to the application of fishing restrictions, the objective of the Tana Agreement seems to comply with Article 15(1) of ILO 169. The following appears to be a logical consequence: If restrictions are required for ecological reasons, measures should primarily reduce fishing tourism (Finnish holiday home owners' fishing included), and thus "especially safeguard" Sami fishing, according to Article 15(1).

However, some essential elements of the Tana Agreement indicate that the burden of fishing restrictions (also) applies to Sami fishers. Firstly, the Sami fishers are obliged to obtain fishing license to fish in the Tana river. ${ }^{126}$ Secondly, restrictions apply to the fishing season, times and gear. Sami fishers are only allowed to fish during a fixed season on certain days of the week at particular times, e.g. they may fish with driftnets between June 1-15, from Monday at 18:00 to Wednesday at 18:00..$^{127}$

Thus, because of the fact that the Sami fishers are obliged to restrict their fishing to a limited period with particular type of gear, they contribute to a significant decrease in the total catch in the Tana River.

In addition, the Tana Agreement contains various restrictions applicable to visiting fishers, Finnish holiday home owners included. Firstly, a quota of 11000 fishing licenses are granted to both Norwegian and Finnish fishers. ${ }^{128}$ Visiting fishers are also subject to restrictions on fishing season, times and gear. Unlike Sami fishers, visiting fishers are not allowed to use nets for salmon fishing, only rods 
and handlines. ${ }^{129}$ Visiting fishers are allowed to fish during the period 10 June 10 August. ${ }^{130}$

One fishing license applies to one fishing day, with boat fishing starting at 18:00 and beach fishing starting at 22:00, and ending the next day at 18:00 and 15:00 respectively. However, the Finnish holiday home owners benefit from a favorable scheme compared to other visiting fishers. Firstly, a quota of $1 / 3$ of the 11000 Finnish licenses may be reserved for these fishers. ${ }^{131}$ Secondly, the required use of a local rower does not apply. ${ }^{132}$ In addition, they are allowed to use their own boat, ${ }^{133}$ and they may start fishing on June $1 .{ }^{134}$

These provisions indicate that the Finnish holiday home owners enjoy a less restrictive fishing regime on the Tana River than ordinary visiting fishers. Hence, total fishing tourism may be more effective, and involve the risk of increased salmon catches. This risk is further enhanced by the extended "fishing day" granted to the Finnish holiday home owners. According to the Tana Agreement, their fishing day begins at 22:00 and ends the next day at 22:00. ${ }^{135}$ As mentioned above, the ordinary fishing day, applicable to other visiting fishers, ends at 15:00. Thus, the provisions that apply to the Finnish holiday home owners lead to increased fishing pressure compared to a situation where these fishers had been subject to the same regime as ordinary visiting fishers. The extended fishing day for these fishers, is estimated to increase effective fishing time by $12 \% .{ }^{136}$

The question is whether the Tana Agreement's extension of the fishing rights of the Finnish holiday home owners complies with Article 15(1) of ILO 169. As mentioned before, it is the Sami people's fishing tights that "shall be specially safeguarded," not the Finnish visiting fishers or holiday home owners. As the Tana Agreement affirms both an extension of the holiday home owner's fishing rights and restrictions on the Sami fishing, this may imply that ecologically based restrictions on fishing do not apply primarily to visiting fishers, but to the Sami fishers. Considering this, it is questionable whether the Tana agreement especially safeguards the rights of the Sami, and thus complies with Article 15(1) of ILO 169.

For the same reasons, it is questionable whether the Tana Agreement complies with the Norwegian Tana Act. ${ }^{137}$ It follows from $₫ 6$ of the Tana Act and its preparatory work that the objective of the Act is not to protect fishing rights of visiting fishers, and that restrictions on the number of available fishing licenses shall apply primarily to visiting fishers. ${ }^{138}$

\section{Concluding remarks}

International law contains both obligations and guidelines when it comes to management of shared salmon stocks in boundary and transboundary rivers. Both Norway and Finland have dealt with the obligations and guidelines on bilateral cooperation deriving from international law. Through the recently adopted Tana Agreement, Norway and Finland have implemented obligations and guidelines applicable to 


\section{Irene Vanja Dahl}

conservation and management of the salmon stocks in the Tana River. The main focus of the Agreement is on reducing the fishing pressure from long-term overexploitation. There seems to be potential for future expansion of the Agreement to include additional topics, for instance habitat management. Norway and Finland have agreed on establishing joint bodies to implement some of the more specific provisions, currently limited to monitoring, researching and registering catches. There should also be potential to broaden the scope when it comes to the structure of a bilateral agreement body. One promising measure could be for the parties to consider establishing a permanent agreement body, a Tana River Commission, authorized to deal with a broader range of issues like the pink salmon (Oncorhynchus gorbuscha) and its impact on shared stocks. However, it seems likely that Norway and Finland, through the Tana Agreement, will fulfil their overall obligation to conserve the salmon stocks in the Tana River.

On the other hand, Finland and Norway are subject to international law pertaining to indigenous peoples rights. As far as Norway is concerned, ILO 169 applies to Norwegian management and legislation applicable to Sami culture. Exclusion of Sami representation at a significant stage of the negotiation process of the Tana Agreement and the extension of Finnish visiting fishers rights while imposing restrictions on Sami fishing, make it questionable whether the Tana Agreement is in compliance with ILO 169 and the Norwegian Tana Act.

\section{NOTES}

1. "Salmon and People in a Changing World," accessed August 14, 2020, https://yearofthesalmon.org/about_us/.

2. "NASCO, Scientific Advice and Research," accessed August 14, 2020, http://www.nasco.int/ scientificadvice.html.

3. Norwegian Environment Agency, "Wild salmon in Norway," accessed August 14, 2020, https://www.miljodirektoratet.no/aktuelt/nyheter/2018/juni-2018/2019-er-villaksens-ar/.

4. Morten Falkegård and Martin-A. Svenning, "Hvorfor sliter laksen i Tana?," Ottar 316 (2017): 17.

5. Vitenskapelig råd for lakseforvaltning, "Status for norske laksebestander i 2020," Rapport fra vitenskapelig råd for lakseforvaltning 15 (2020): 98-99.

6. Tanavassdragets fiskeriforvaltning, "Tana River - Tana Watercourse," accessed August 14, 2020, http://tanafisk.no/en/tanavassdraget-2/tanavassdraget.

7. Tanavassdragets fiskeriforvaltning, "Deatnu - Tanaelva,"accessed August 14, 2020.

8. Tanavassdragets fiskeriforvaltning, "Fangststatistikk for Tanavassdraget," accessed August 14, 2020. http://tanafisk.no/statistikk/fangststatistikk.

9. Prop. 54 S (2016-2017) Samtykke til inngåelse av avtale mellom Norge og Finland om fisket i Tanavassdraget (Proposition to the Norwegian Parliament on consent to conclude agreement between Norway and Finland on fisheries in the Tana Watercourse), 7.

10. Norwegian Environment Agency, "Lakseregisteret - Tanaelva," accessed August 14, 2020, https://lakseregisteret.fylkesmannen.no/visElv.aspx?vassdrag=Tanaelva\&id=234.Z.

11. Ibid.

12. Prop. 54 S (2016-2017), note 9, 7. 


\section{International Regulations and Guidelines on Transboundary Salmon Stocks}

13. Ibid.

14. Avtale mellom Norge og Finland om fisket i Tanavassdraget (Agreement between Norway and Finland on fishing in the Tana Watercourses), adopted April 9, 2016, entered into force January 5, 2017, published in Overenskomster med fremmede stater (Agreements with foreign states) $2017,223$.

15. 1833 UNTS 399.

16. Rosemary Rayfuse, Non-Flag State Enforcement in High Seas Fisheries (Leiden: M. Nijhoff, 2004), 33.

17. J. Ashley Roach, "Today's Customary International Law of the Sea," Ocean Development $\mathcal{E}$ International Law 45 (2014): 239-259, 247.

18. 1760 UNTS 69 .

19. CBD Article 7.

20. CBD Article 8.

21. CBD Article 9.

22. CBD Article 10.

23. Christine Willmore, "Sovereignty, conservation and sustainable use," in Biodiversity and Nature Protection Law, eds. Elisa Morgera and Jona Razzaque (Cheltenham: Edward Elgar, 2017), 37.

24. NASCO, Handbook of Basic Texts, 2, http://www.nasco.int/pdf/reports_other/NASCO_ Handbook.pdf.

25. Ibid.

26. Ibid.

27. Ibid., 7-19.

28. NASCO Convention Article 3(2).

29. Ibid., Article 3(1).

30. Ibid., Article 3(4).

31. NASCO: North-East Atlantic Commission, accessed August 14, 2020, www.nasco.int/neac measures.html.

32. For an analysis of regional approaches to aquaculture, with a case study of NASCO, see Irene Dahl, "Regional approaches to aquaculture and a case study of the North Atlantic Salmon Conservation Organization," in Aquaculture Law and Policy: Global, Regional and National Perspectives, eds. Nigel Bankes, Irene Dahl and David L.VanderZwaag (Cheltenham: Edward Elgar, 2016), 103-29.

33. 1650 UNTS 383.

34. See the Supreme Court of Sweden in the "Girjas" judgement, T-853-18.

35. Lov 20. juni $2014 \mathrm{nr} .51 \mathrm{om}$ fiskeretten i Tanavassdraget (Tanaloven/the Tana Act).

36. NASCO: Agreement on Adoption of a Precautionary Approach, CNL(98)46.

37. NASCO: Plan of Action for the Application of the Precautionary Approach to the Protection and Restoration of Atlantic Salmon Habitat, CNL(01)51.

38. Ibid., 1. Introduction.

39. Ibid.

40. NASCO, “About NASCO,” accessed August 14, 2020, http://www.nasco.int/about.html.

41. CNL(01)51, note 39, 1 . Introduction.

42. Ibid., 3. Guiding Principles.

43. NINA (Norwegian Institute for Nature Research), "Registrerer utbredelsen av pukkellaks i Norge," accessed August 14, 2020, https:/www.nina.no/V\%C3\%A5re-fagomr\%C3\%A5der/ Pukkellaks.

44. Ibid.

45. VKM Report 2020: 01, Assessment of the risk to Norwegian biodiversity and aquaculture from pink salmon (Oncorhynchus gorbuscha), 10. 


\section{Irene Vanja Dahl}

46. Statistics Norway, “Over 10 tonn uønska laks fiska,” accessed August 2014, 2020, https://www. ssb.no/jord-skog-jakt-og-fiskeri/artikler-og-publikasjoner/over-10-tonn-uonska-laks-fiska.

47. NINA (Norwegian Institute for Nature Research), "Rekordmange pukkellaks i Norge 2019," accessed August 2020, https://www.nina.no/Aktuelt/Nyhetsartikkel/ArticleId/4969/ Rekordmange-pukkellaks-i-Norge-2019.

48. VKM Report 2020: 01, note 48, 11.

49. Ibid.

50. Ibid., 11-12.

51. Ibid.

52. Ibid., 12.

53. Ibid., 13.

54. Ibid., 13-14.

55. Ibid.

56. Ibid., 14 .

57. Ibid., 15.

58. Ibid., 15.

59. CNL(01)51, note 39, 5. Salmon Habitat Protection and Restoration Plan.

60. NASCO: Guidelines for the Management of Salmon Fisheries, CNL(09)43.

61. Ibid., 1. Introduction.

62. Ibid., 2. Key elements of management.

63. Ibid., 2.2.a.

64. Ibid., 2.3.a.

65. Ibid., 2.3.b.

66. Ibid., 2.3.c.

67. NASCO: Guidelines on the Use of Stock Rebuilding Programs in the Context of the Precautionary Management of Salmon Stocks, CNL(04)55.

68. Ibid., 2 .

69. Ibid., 3 .

70. Ibid.

71. Ibid., 4 .

72. Ibid., 6 .

73. CNL(98)46., note 38 .

74. CNL(01)51, note 39, 5. Salmon Habitat Protection and Restoration Plans.

75. Prop. 54 S (Proposition to the Norwegian Parliament), (2016-2017), 5.

76. Note 15.

77. Stortinget, "Samtykke til inngåelse av avtale mellom Norge og Finland om fisket i Tanavassdraget av 30. september 2016," accessed October 15, 2020, https://www.stortinget.no/no/ Saker-og-publikasjoner/Vedtak/Vedtak/Sak/?p=67775.

78. Riksdagens pressmeddelanden, "Riksdagen godkände fiskeavtalet för Tana älv," accessed October 15, 2020, https://www.eduskunta.fi/SV/tiedotteet/Sidor/Riksdagen-godkande-fiskeavtalet-for-Tana-alv.aspx.

79. Tana Agreement, Article 1(1).

80. Ibid., Article 1(3).

81. Ibid., Article 4.

82. Ibid., Article 4(3).

83. Note 39.

84. Note 65.

85. Note 79.

86. Note 65, 2.3.a. 
87. Tana Agreement, note 91 Annex 2.

88. Prop. 54 S (2016-2017), 7.

89. Ibid.

90. Ibid.

91. Tana Agreement, Article 14(2).

92. Ibid., Articles 15(6) and 16(1).

93. Ibid., Article 12(2).

94. Ibid., Article 12(1).

95. Ibid., Article 7(1).

96. Ibid., Article 12(1).

97. Ibid., Article 7(1).

98. Ibid., Article 12(2).

99. Research and monitoring, accessed October 12, 2020, http://tanafisk.no/statistikk/forskning.

100. Ibid., Article 11(2).

101. Ibid., Article 11(3).

102. Ibid., Article 13(1).

103. Tana Agreement, Annex 2 Article 30.

104. Tana Agreement Article 17(1).

105. Tana Act, note 37.

106. Prop. 54 S (Proposition to the Norwegian Parliament), (2016-2017), 10.

107. Tana Agreement, Annex $2 \S 4$.

108. Prop. 54 S (Proposition to the Norwegian Parliament), (2016-2017), 10.

109. Øst-Finnmark tingrett, judgement of October 9, 2020, case 19-103225TVI-OSFI.

110. ILO Convention on Indigenous and Tribal Peoples, 1989 (No. 169): A Manual, Geneva International Labour Office, 2003, 30.

111. Prop. 54 S (Proposition to the Norwegian Parliament), (2016-2017), 18.

112. ILO A Manual, note $117,15$.

113. Ibid.

114. Ibid., 17.

115. Ibid.

116. Endalew Lijalem Enyew, "Application of the Right to Permanent Sovereignty over Natural Resources for Indigenous Peoples: Assessment of Current Legal Developments," Arctic Review on Law and Politics, 8 (2017): 222-245, 239.

117. Regjeringen, "Norsk-finsk avtale om fisket i Tanavassdraget," accessed August 14, 2020, https://www.regjeringen.no/no/aktuelt/norsk-finsk-avtale-om-fisket-i-tanavassdraget/ id $2537660 /$.

118. Note 124.

119. Prop. 54 S (Proposition to the Norwegian Parliament), (2016-2017), 18.

120. Prop. 54 S (Proposition to the Norwegian Parliament), (2016-2017), Appendix 3, 51-53.

121. Ibid.

122. Ibid.

123. Prop. 54 S (Proposition to the Norwegian Parliament), (2016-2017), 22.

124. Ibid.

125. Tana Agreement, Article 1(1).

126. Tana Agreement, Article 10(2), cf. Tana Agreement, Appendix $2 \rrbracket 4(1)$.

127. Tana Agreement, Appendix $2 \$ 6$, cf. $₫ 13$.

128. Tana Agreement, Article 5.

129. Tana Agreement, Appendix $2 ₫ 6$.

130. Ibid., $₫ 8(2)$. 


\section{Irene Vanja Dahl}

131. Ibid., $\ 5(4)$.

132. Ibid., $₫ 9(4)$.

133. Ibid., $\$ 36(4)$.

134. Ibid., $₫ 8(3)$.

135. Ibid., $₫ 9(2)$.

136. Tanavassdragets fiskeriforvaltning (Tana Watercourse's Fisheries Management), "Juridisk vurdering av innføring av ny rettighetsgruppe”, accessed August 14, 2020, http://tanafisk. no/juridisk-vurdering-av-innforing-av-ny-rettighetsgruppe/6104.

137. Note 37.

138. Prop.58 L (Proposition to the Norwegian Parliament) (2013-2014), 3.1.4. 